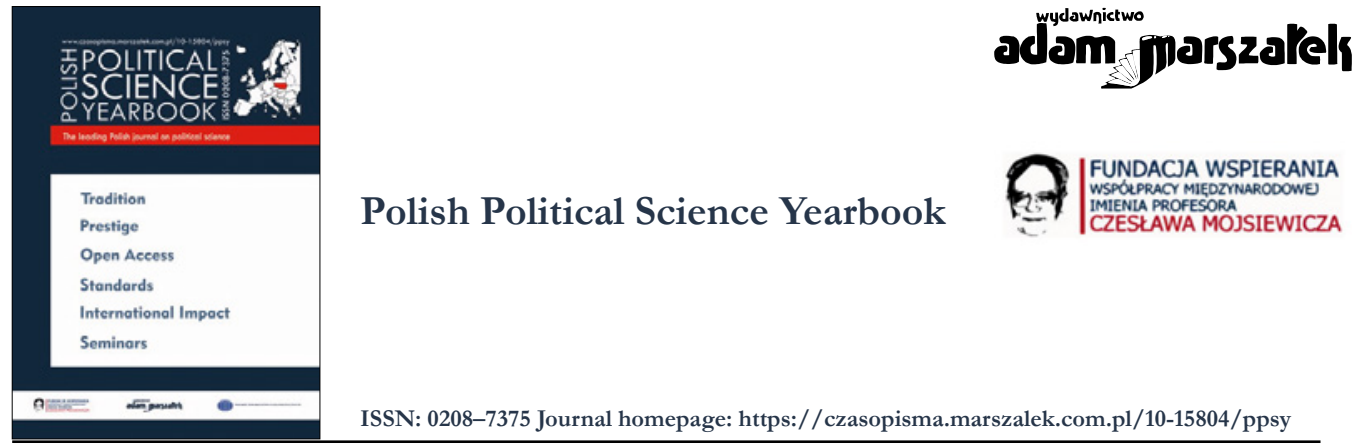

\title{
Economic Sanctions as a Tool of China's Hybrid Strategies
}

\section{Rafał Wiśniewski}

ORCID: 0000-0002-0155-246X

To cite this article please include the following information:

- Journal title: Polish Political Science Yearbook

- Volume number: 50

- Year of publication: 2021

- Published ahead-of-print

Example styles:

[APA Style]: Wiśniewski, R. (2021). Economic Sanctions as a Tool of China’s Hybrid Strategies. Polish Political Science Yearbook, 50(issue number), pages. https://doi.org/10.15804/ppsy202133

[Chicago Style]: Rafał Wiśniewski, "Economic Sanctions as a Tool of China’s Hybrid Strategies" Polish Political Science Yearbook 50, no. [issue number] (2021).

To link to this article: https://doi.org/10.15804/ppsy202133

Published ahead-of-print

\begin{tabular}{l} 
Final submission: 30 June 2021 \\
\hline Published online: $\quad$ 10 July 2021 \\
\hline Printed issue: $\quad$ December 2021 \\
\hline Submit your article to PPSY
\end{tabular}




\title{
Rafał Wiśniewski
}

Adam Mickiewicz University (Poland)

ORCID: 0000-0002-0155-246X

e-mail: rafal.wisniewski@amu.edu.pl

\section{Economic Sanctions as a Tool of China's Hybrid Strategies}

\begin{abstract}
The article aims to analyze the role of economic sanctions in the People's Republic of China's overall approach to achieving its security objectives in the international arena. During the last two decades, Beijing used this instrument on numerous occasions to exert pressure on a varied group of actors. China's current strategy toward a range of disputes and conflicts it is engaged in (the South China Sea territorial disputes most prominently stand out) is often described using the popular vocabulary of "hybrid warfare" or "grey zone conflicts". Putting the conceptual complications aside, the author agrees that the PRC's approach can be viewed as part of a growing trend for great powers to employ what can be called "hybrid strategies" toward its opponents. As part of a broader category of economic statecraft, economic sanctions form an important element of this approach. Considering current scholarship on both "hybrid" (or "grey area") warfare and economic sanctions, the article answers the question of why the PRC increasingly resorts to hybrid strategies (including economic coercion) and identifies the main characteristics of Chinese economic sanctions. It also provides preliminary conclusions on their effectiveness.
\end{abstract}

Keywords: coercion, hybrid warfare, People's Republic of China, economic sanctions

The first two decades of the XXIst Century witnessed the People's Republic of China's gradual ascent to the second most powerful state in the international system ${ }^{1}$. This reality makes the objectives, strategies, and instruments of its grand strategy a focus of intense analysis and commentary. This article aims to dissect the role of economic sanctions in China's overall approach to achieving its security objectives in the international arena. China's current strategy toward a range of disputes and conflicts it is engaged in (the South China Sea territorial

1 As argued in, e.g., Brooks \& Wohlforth (2016) or Wisniewski \& Hensarling (2015). 
dispute most prominently stands out) often is described using the popular vocabulary of "hybrid warfare" or "grey zone conflicts". Putting the conceptual complications aside, the author agrees that the PRC's approach can be viewed as part of a growing trend for great powers to employ what can be called "hybrid strategies" toward its opponents. As part of a broader category of economic statecraft, economic sanctions form an important element of this approach. In order to better understand and interpret these phenomena, this paper will aim to answer the following research questions:

1. Why does the PRC increasingly resort to economic sanctions as a coercive foreign policy tool?

2. What are the main characteristics of Chinese economic sanctions, and how they relate to their effectiveness?

The paper proceeds in the following order. First, it presents the concept of hybrid strategies and their role in current Chinese security policy. Particular emphasis is put here on economic sanction's role in this broader strategic approach. In the next step, the instances of economic sanctions' employment are being analyzed to identify the main characteristics of Beijing's practice of their employment. Finally, preliminary conclusions on the role of sanctions in the PRC's foreign and security policies are being offered.

\section{Hybrid Strategies in Chinese Security Policy}

During the last two decades, the strategic studies community has intensely debated the changes to how both state and non-state actors engage in armed conflicts. The interlinked concepts of "hybrid warfare" and "gray area conflict" have been used to describe and explain the complex mix of military and non-military means employed both overtly and covertly by various actors to prevail against their opponents (Altman, 2018; Libiseller \& Milevski, 2021). In another publication, the author has provided a wider examination and literature review on the hybrid warfare concept (Wisniewski, 2018). It indicates that contemporary thinking on hybrid warfare (or hybrid conflict) can be traced back to three main sources: Western strategic thought, Chinese Unrestricted Warfare concept, and Russian ideas on Next-Generation Warfare. For the sake of this paper, there is no need to characterize all of them closely. However, considering the topic at hand, it is useful to cite the Chinese concept of Unrestricted Warfare.

The concept has been presented in the 1999 book Unrestricted Warfare by Qiao Liang and Wang Xiangsui (both served in the rank of senior colonel in the People Liberation Army Air Force at that time). Analyzing the 1990-91 Gulf War and further military operations conducted by the USA and its allies, they concluded that the nature of war has been significantly changed by advances in technology and socio-political conditions. They proposed a concept of 'unrestricted warfare', defined as: "using all means, including armed force or non-armed force, military and non-military, and lethal and non-lethal means to compel the enemy to accept one's interests" (Qiao Liang \& Wang Xiangsui, 1999, p. 7). Drawing on 
Sun Tzu's reflections on warfare, the authors stress that war can and must be conducted in many dimensions and with diverse means. In their opinion, the successful conduct of war requires a skillful combination of the military (for example, nuclear, conventional, space, or guerrilla), trans-military (among others: diplomatic, psychological, or network), and non-military (such as financial, trade, ideological) modes of warfare (Qiao Liang \& Wang Xiangsui, 1999, pp. 124-148). They propose a model of "combined war that goes beyond limits" (Qiao Liang \& Wang Xiangsui, 1999, p. 182). In order to wage it, one must: “(..) 'combine' all of the resources of war which he has at his disposal and use them as means to prosecute the war" (Qiao Liang \& Wang Xiangsui, 1999, p. 181). Moreover, it is necessary to: "go beyond the intrinsic boundaries of a certain area or a certain direction, and to combine opportunities and means in more areas or in more directions, so as to achieve a set objective" (Qiao Liang \& Wang Xiangsui, 1999, pp. 181-182).

After a review and analysis of all three aforementioned strands of thought on "hybridity" the author has proposed to conceptualize this phenomena as hybrid strategies. A hybrid strategy is a coordinated (strategic) and coercive employment of a flexible combination of power tools (military, political, economic, social, informational, etc.), fluidly adjusted across time and space to exploit opponent's vulnerabilities to achieve strategic political objectives through the erosion of opponent's political will to resist.

There are two aspects of hybrid strategies:

- Hybrid warfare: joint employment of different combat modes - regular, irregular, terrorist - during armed conflict.

- Hybrid coercion: coordinated employment of military and non-military (violent and non-violent) power tools in the frame of a political conflict (armed or otherwise).

As seen in these definitions, hybrid warfare is a military strategy, which can be one of the elements of hybrid coercion. At the same time, hybrid coercion can be employed without actual recourse to armed struggle (temporarily or permanently) (Wisniewski, 2018,pp. 98-101).

When it comes to the case of China, we can see signs of hybrid strategies' employment, primarily during the last decade. The most prominent case entails Beijing's actions in the South China Sea, where activities of the People's Liberation Army Navy, maritime law enforcement agencies, and maritime militia have been orchestrated to further China's territorial claims (Martinson, 2018; Gady, 2015). When coupled with land reclamation, propaganda, and "lawfare" efforts, these actions pretty much amount to a hybrid coercion campaign (see, for example, Laity, Nimmo, Jackson, and Thomas, 2015; Ayson \& Pardesi, 2017).

Economic instruments play an important role in Chinese efforts to influence the international environment. Beijing's skilled use of economic inducement and coercion has attracted considerable attention of analysts. Economic sanctions are naturally an important part of these efforts. Before we turn to the analysis of the PRC's sanction practices, let us first identify factors contributing to China's increased usage of hybrid coercion. 
I. Increasing Chinese assertiveness following the financial crisis. It became a staple of China watchers to identify the turn of the first and second decade of this century as a turning point in the evolution of Chinese foreign policy. After two decades of "keeping a low profile" and "hiding capabilities", as prescribed in Deng Xiaoping's 24-character instruction, Beijing gradually switched to a more muscular posture in regional disputes and greater confidence in making its voice heard on the global stage. This change is usually explained by Chinese leaders' perception of the global financial crisis's effects on the global balance of power. It amounted to a vision of accelerating American decline and a corresponding strengthening of the Chinese position. This trend toward greater assertiveness in foreign policy has only accelerated under Xi Jinping's leadership. "The Third Revolution" in Chinese domestic and foreign policy (as named by Elizabeth Economy- Economy, 2018) amounted to phasing out Deng Xiaoping's dictum and adopting a new approach of "striving for achievement" in diplomacy (Swaine, 2018). Such bold proposals as the Belt and Road Initiative (BRI) or the Asian Infrastructure Investment Bank (AIIB) became symbols of this newly prominent ambition in Chinese foreign policy. When coupled with growing material attributes of power (GDP, outbound FDI, military spending and capabilities, foreign military base, etc.), it signaled that the PRC is a prominent global power and aims to act accordingly.

II. Escalating rivalry with the United States. As the global balance of power shifted toward $1+x+y$ equilibrium (meaning the USA + China + other great powers) (Brooks \& Wohlforth, 2016) and the catalog of US-China disagreements widened, a looming shadow of bipolarity descended upon international order (or at least its Asian regional part). The Sino-American relationship has been marked by rivalry since the inception of the People's Republic. However, the mentioned shift in Chinese foreign policy and American reaction significantly raised mutual insecurity between these two powers. Consequently, the equilibrium between cooperation and competition in their bilateral relationship decidedly moved toward the competitive end of the spectrum (Poast, 2020). The open declaration of China as a strategic competitor in the 2017 US National Security Strategy (National Security Strategy of United States of America, 2017, pp. 2-3) had just been a final confirmation of mutual antagonism, if not outright hostility. It can be argued that the entire international security environment of the Asia-Pacific, with all its varied conflicts and security issues, is being increasingly subsumed into an overarching bipolar rivalry between Beijing and Washington. This dynamic is another factor pushing Chinese leaders toward increased usage of coercive tools.

III. Military asymmetry and strategic stalemate. Hybrid strategies became an attractive option for many powers precisely because outright military confrontation remains an unappealing one. Despite impressive increases in military expenditure and accompanying growth of military capabilities, the Chinese military is still 
not an exact peer to US forces. Serious doubts remain about its capability to fight a modern war, even (as it seems) in its ranks (Blasko, 2019). For that reason, it seems reasonable to expect that Chinese leaders would avoid direct military conflict with the United States and/or its allies. Moreover, great power belligerence, in general, is still constrained by what can be called a "strategic stalemate". The author understands it as a balance of power in which both rivals perceive the potential costs of an open war between them as too high to risk such an outcome. This stalemate persists in USChina relations due to several mutually reinforcing trends. The traditional nuclear balance of terror has been enhanced by growing cyber and space attack capabilities, making potential war immensely costly. Moreover, the mutual economic interdependence also constraints belligerence. The Sino-American trade war initiated by Donald Trump's administration only proves this point. Despite the heightened rhetoric, both sides had shown significant interest in a negotiated compromise as an alternative to the escalation of tensions. With large-scale use of military force effectively impractical, hybrid strategies become ever more enticing options for decision-makers. In this context, economic sanctions can be viewed as an attractive tool for furthering one's interests (deterring unwanted behavior or establishing a new international status quo) without risking open military conflict.

\section{Chinese Use of Economic Sanctions}

The preceding section has outlined the case for increased use of hybrid coercion in Chinese foreign and security policy. This section will focus on one of its tools - economic sanctions. It is appropriate to specify how this particular instrument of foreign policy is defined for this article. In studying Chinese policy, it is especially important to acknowledge the relationship between two closely related concepts: economic sanctions and economic coercion. The popular view of economic sanctions (based on the form they most often take in Western practice) equates them with measures introduced by a legal act issued by relevant authorities of the sender state, accompanied by public declaration specifying the objectionable political actions of the target state and changes to it which the sanctions are meant to effect. Most of the actions undertaken by the PRC (which will be specified and analyzed further in the article) do not satisfy these criteria. Their unofficial and unacknowledged nature leads some observers to call them economic coercion rather than economic sanctions. However, the author decided to adopt the definition applied in the Threat and Imposition of Economic Sanctions (TIES) dataset: "Economic sanctions are defined as actions that one or more countries take to limit or end their economic relations with a target country in an effort to persuade that country to change its policies" (Clifton, Bapat, and Kobayashi, 2014, p. 5). Based on such an understanding of the issue, it can be argued that the distinction between economic sanctions and economic coercion is rather superficial. That is why the author decided to treat all instances of economic pressure applied by the PRC for political ends 
as relevant for this article. The term "economic sanctions" will be applied to all of them, as allowed by a relatively broad TIES dataset definition. This approach is similar to the one adopted by David Baldwin, who criticized the term "economic sanctions" as too vague, but (due to its pervasive use) decided to apply it as synonymous with economic statecraft (Baldwin, 1985, pp. 35-36).

Traditionally PRC was quite reluctant to use economic sanctions. It has chosen this option far less often than leading Western powers. The TIES dataset (covering the 19452005 period) includes 20 instances of China being the primary sender of sanctions, and they all deal with cases initiated in the 1940s (Clifton et al., 2014). It can be explained by PRC's relative economic weakness at the time and its struggle as a target of sanctions. Importantly, Tong Zhao (2010) points out that Chinese leadership remained skeptical toward implementing such measures due to its own experience of successfully resisting strategic economic sanctions (understood as those deemed to threaten the regime itself). He concluded that as China tended to yield only to tactical sanctions (those with more limited aims), it translated its experience into its own sanctions policy amounting to the usage of only limited, tactical sanctions.

As the Chinese economy's role in the global capitalist system grew, its ability to exercise economic coercion raised correspondingly. In this century's second decade, the PRC started to use this option more often and more forcefully. The most prominent cases from 2010-2021 include ${ }^{2}$ :

1. Restriction of rare earth metal's exports to Japan during an escalation of the island territorial dispute in 2010.

2. Impediments to Norwegian salmon imports after Nobel Peace Prize award to Chinese dissident Liu Xiaobo in 2010.

3. Alleged punitive measures against the Philippines during the Scarborough Shoal standoff in 2012.

4. Economic restrictions adopted against Taiwan after the island's 2016 presidential election.

5. Impediments to trade with Mongolia after Dalai Lama visited the country in 2016.

6. Economic reprisals against South Korea after the deployment of the US Ballistic Missile Defense system THAAD on the peninsula in 2017.

7. Potential limitation on Chinese students' enrolment at Australian universities starting 2017.

2 The list is based on: (Harrell et al., 2018; Hufbauer \& Jung, 2020; Bush \& Xu, 2021). The CNAS report also includes the cases of PRC's involvement in multilateral sanctions on Iran and North Korea. However, for the purpose of this paper, the author would like to focus on instances of China's employment of unilateral economic sanctions. 
8. Restrictions on imports of Canadian goods to China in response to the detention of Huawei executive Meng Wanzhou in 2019.

9. Suspending broadcasts of NBA games following a social media post of one team's official, supportive of Hong Kong protests in 2019.

10. Restrictions on imports from Australia following Huawei's exclusion from that state's $5 \mathrm{G}$ infrastructure and (most prominently) calls for an independent inquiry into the origins of the COVID-19 Pandemic in 2020.

11. Sanctions (including travel and business dealings bans) on the US, the EU, Canadian, and British persons and entities involved in criticism of Chinese human rights record (specifically Hong Kong and Uighur repression) in 2020-2021.

12. Sanctions on US defense companies involved in arms sales to Taiwan in 2020.

13. Consumer boycotts of Western clothing companies following initiatives to address the issue of forced Uighur labor in Xinjiang's cotton industry in 2021 ("Swept up in a storm", 2021).

Based on this limited body of cases and literature review, the following characteristics of Chinese sanctions behavior can be identified.

I. Goals. As already mentioned, Chinese leaders instinctively restrict the scope of sanctions to limited, tactical goals. We can see that China reacts to perceived infringement of its "core interests" and usually aims to pressure target countries to correct certain behavior and/or refrain from it in the future (Harrell et al., 2018, p. 13). It is the first important difference with the approach of Western states. Beijing generally does not aim to change regimes in target states or force them to abandon key and longstanding policy approaches. It rather aims to eliminate unwanted behavior. Based on the existing body of literature on sanctions ${ }^{3}$, we can establish that they tend to serve three basic sets of functions: 1) bargaining - convincing the target to modify/abandon its behavior; 2) punishment - inflicting pain for perceived infringement of sender's interests and implicitly deterring similar behavior in the future; 3 ) posturing - signaling to the domestic and foreign audience that sender cares about the issue at stake and takes some action to change the situation. Looking at Chinese sanctions' behavior from this perspective, it can be claimed that measures adopted by Beijing are serving all three purposes. However, we can reach a tentative conclusion that the weight of particular functions in decision-making is not even. The authors of the CNAS study mention that economic sanctions are also used to satisfy the domestic nationalist sentiment awaken by other states' behavior (Harrell et al., 2018, p. 22). Considering this observation, it must be noted that adopted measures' unofficial and deniable character limits the posturing effect of sanctions. It seems that Chinese leadership is specifically designing its sanctions policy in a way to avoid the domestic political costs of potential failure and abandonment of

\footnotetext{
3 The analysis of sanctions' functions is based on (Pape, 1997; Drezner, 2003; Allen, 2005).
} 
imposed measures. In the cases at hand, bargaining behavior is easily identifiable. The minimal and tactical character of adopted sanctions indicates that they are meant to modify the target's immediate behavior. However, it can be argued that Chinese sanctions are also, at their core, punitive measures aimed at establishing effective deterrence against potential future challenges to Beijing's core interests. The CNAS study also highlights the effect of perception management of this economic coercion (Harrell et al., 2018, pp. 29-30). Thus it can be argued that Beijing is applying punitive economic measures to demonstrate to the entire international community the effects of incurring its ire. Thanks to that, it may not have to apply sanctions again, as the deterrent effect will be achieved. It seems to go along with the thinking of Drezner (2003), who observes that threatened sanctions can be more effective than enforced ones.

II. Targets. In most analyzed cases, China was targeting smaller and democratic states. The primary reason is the mere fact that these are the states with which China has its most acute disputes. However, it is difficult not to see a parallel here with research findings claiming that democratic targets are more likely to acquiesce due to domestic political pressure. An important caveat is that, with time, democratic regimes tend to stiffen their spines thanks to the rally-the-flag effect (Allen, 2005). Relating this to the Chinese sanctions policy, we can see that the Chinese limited duration, limited goals, and a heavy pressure approach are nicely suited to extract quick concessions from democratic states. It is achievable thanks to smartly targeting sanctions at key political constituencies (Harrell et al., 2018,pp. 20-21) and resolving the issue relatively quickly before national mobilization takes hold.

III. Instruments. The most widely cited and analyzed characteristic of Chinese economic sanctions is their unofficial and comprehensive nature. In the majority of cases under consideration, the imposition of sanctions has never been officially promulgated. In most instances, the PRC authorities denied the fact that sanctions have been applied. Instead, they were pointing out that China is merely enacting its unrelated legislation (dealing with, for example, environmental protection or sanitary requirements) or that the actions are being taken by the public (consumer boycotts). This situation leads to significant confusion as to whether economic sanctions have been applied. Serious voices argue that foreign observers have misrepresented unrelated events as economic sanctions (Poh, 2017; Harrell et al., 2018). As resolving these dilemmas is beyond the author's competences, it can only be observed that if China was really aiming for plausibly deniable economic sanctions, that would be exactly the desired effect. In most instances, the PRC used its huge domestic market size and allure as the main pressure point. Import restrictions, consumer boycotts, or impediments to foreign companies' operation in China count among the most widely used instruments. It is also important to note that the high level of the Chinese state's influence (or outright control) over the economy allows for the 
mobilization of commercial and public forces for economic coercion without formal legal action (Harrell et al., 2018, p. 22). However, it is important to note important changes in the PRC's sanctions policy in 2020-21. What is new are official, targeted sanctions on Western politicians and entities in response to criticism of China's domestic policies. These are very similar to more traditional sanctions deployed by Western states. It is hardly surprising, considering that they are basically a retaliation for corresponding measures adopted by Western governments. Their goals are punishment and posturing. It raises the question of whether the PRC's sanctions policy is undergoing a shift toward a framework more similar to a formal, legal, state-led Western approach. It is too early to present a definitive conclusion on that. On the one hand, the new measures can be viewed as direct, in-kind retaliation for Western sanctions. In that sense, there are mimicking original measures directed at China. It is unclear whether they signal a broader shift in Chinese sanctions policy or whether they will remain a special kind of strictly retaliatory instruments. On the other hand, the PRC government has created a comprehensive legal framework for sanction's imposition and enforcement (Bush \& Xu, 2021). It may point in the direction of innovation's more durable character.

\section{Conclusions}

Based on the preliminary analysis of the presented Chinese sanctions policy, several reflections emerge. It is pretty difficult to formulate strong conclusions about the usage of economic sanctions by the People's Republic of China. As already mentioned, Beijing turned into this coercive economic measure recently. In consequence, the body of cases to study is pretty limited. The picture is even more obscured by informal ways in which sanctions often are being employed by China and the uncertainties it creates. When scholars disagree even on a basic question of whether sanctions occurred or not, it is clear how difficult this research area is. From limited data available, a picture emerges of economic sanctions as one of the tools in a wider spectrum of hybrid coercion mechanisms wielded by Beijing to guard its core interests and prevail against rivals and opponents. It is a very flexible tool indeed. Compared with Western sanctions, the Chinese equivalents are informal, deniable, comprehensive, and relatively short-term. Lack of formal promulgation and reliance on unrelated regulations and actors makes Chinese sanctions policy very malleable and adaptable. Thanks to that, Chinese decision-makers can easily modify their stance without constraints imposed by enacted legislation or public commitments. However, it must be noted that in 2020 China adopted a more formal sanctions framework. Thus far, it has been used in a limited number of cases as retaliation for corresponding Western sanctions.

Naturally, differences in sanctions employment visible between China and Western states can also be explained by starkly different political, legal, and economic systems operating 
in these states. The structure and capacity of the state's institutional system are important factors influencing the effectiveness of economic sanctions and other tools of economic statecraft (Farrell \& Newman, 2019; Kalyanpur \& Newman, 2018). In this regard, it can be observed that although (up until 2020) the PRC possessed very little in terms of a regulatory regime for sanctions' enforcement, the immense (and often informal) influence of the party-state over the economy allowed it to enact punitive economic measures directed at foreign actors effectively. It is also interesting to look at how regime type differences might account for varied sanctions policies. The sanctions literature has been able to detect several patterns in this regard, depending on whether the initiating regime is autocratic or not. Lektzian and Souva indicate a preference among autocracies to opt for comprehensive trade restrictions when sanctioning other states (Lektzian \& Souva, 2003). In contrast, democracies prefer more targeted financial measures. It is probably due to democratic leaders' desire to minimize the negative economic effects of sanctions on broad domestic interest groups. Chinese policy analyzed throughout this article proves to be an interesting testing case for this proposition. The majority of punitive measures adopted by Beijing can be classified as trade restrictions. However, in most cases, these were import restrictions on products that could easily be obtained from other suppliers. Sanctions against Australia from 2020 are a case in point. Such products as wine or seafood could easily be imported from other states. However, the imports of iron ore (of which Australia is China's important supplier) have not been subject to any restrictions (Rajah, 2021). It may point to a more selective sanctions regime, trying to minimize negative effects on the Chinese economy.

Another important insight into regime type differences in sanctions policy comes from McLean and Taehe Whang's (2014) work concerning domestic politics' influence on sanctions' design. These authors claim that particular measures often are designed not with coercive effectiveness in mind but rather are a product of an interplay between various domestic interests. Their thesis is that sanctions are often being initiated in response to public pressure but then watered down due to lobbying by business interests that might be adversely affected by them. If this pattern was universal, it could be expected that the sanctions policy of an authoritarian state (like the PRC) would be more effective, as the mentioned constraints of democratic governance would not apply. Trying to test this hypothesis in the Chinese case is difficult, mainly because its decision-making process is notoriously opaque and resistant to scrutiny. However, at least one element of this puzzle lends itself to some closer examination. The influence of public opinion on the PRC's foreign policy direction has attracted considerable scholarly interest (Duan Xiaolin, 2017; Weiss, 2019). It often is claimed that the Chinese public's nationalist sentiments act as a constraint on government policy. In this reading, the party and state leadership would feel pressure to adopt an assertive posture toward perceived transgressions of Chinese national interests in fear of possible social backlash. The opposite view holds that "patriotic ire" in China is state-managed and used as a tool of the party-state's policies. Data and other empirical observations available at the time of writing do not settle this dispute conclusively. It is impossible to tell with certainty 
whether public opinion is an independent force shaping the PRC's foreign (and sanctions) policy or whether it is effectively controlled and instrumentalized by the authorities. It feels safe to assume that Chinese decision-makers at least take possible public reactions into account when weighing different options available in relations with the outside world. If that was the case, then McLean's and Taehee Whang's conclusions would be at least half true for China. It is possible that economic sanctions are being initiated in response to foreign actors' actions which might be perceived as "offending the feelings of the Chinese people". In this way, the regime might direct social emotions at foreign targets and preempt any accusations of not being decisive enough to defend the country's national interests.

As to the question of Chinese sanctions' effectiveness, any conclusions are necessarily preliminary. It seems that in almost all cases considered, Beijing had been able to extract at least partial concessions from target states. It has taken the form of acts of contrition (in the case of Norway, Philippines, or Mongolia) or diplomatic declarations recognizing at least some of Beijing's demands (like the one made by South Korea regarding future THAAD deployments) (Harrell et al., 2018, p. 29). That would provide arguments for the sanctions' at least partial success. However, the argument can (and is) being made that Beijing has achieved short-term success in influencing target states' behavior. However, in the long-term perspective, the experience might have led the targets to adopt mitigating measures to better confront Chinese pressure in the future. Thus, states in active or potential disputes with China might turn to strategies to lessen their dependence on economic ties with the PRC (Harrell et al., 2018). It seems that exactly this happened in Chinese sanctions directed at Canada and Australia in 2019-2020. Both governments did not significantly alter the "offending" policy. Moreover, political attitudes toward the PRC turned much more critical ("Hostage diplomacy", 2021; "Closing argument", 2021). It can be argued that China's ability to coerce through sanctions is derived from its position as one of the global economy centers. It is especially true for East Asia, with "Factory China" still at the center of its regional production and trade networks. If, however, the trend toward more closed regional trade blocs persists, Beijing's ability to enforce its will through economic coercion will diminish. It might be one reason for China's opposition to the Trans-Pacific Partnership and its promotion of alternative schemes. Such considerations shed new light on the Chinese Belt and Road Initiative and corresponding visions of Eurasian economic integration. A lot has been written about "debt-trap diplomacy" as a risk for states participating in the project (Harrell et al., 2018). Putting aside whether this characterization of Chinese loan policy is accurate or not, we can assume that creating a China-centered economic bloc bound together by trade, investment, and loans would allow Beijing to wield overwhelming influence in its neighborhood.

The only solid conclusion that can be offered at this point is that Chinese sanctions policy is markedly different from Western practice. As the latter has informed most sanctions research to date, the study of these other (non-Western and authoritarian state-initiated) sanctions practice offers a very promising avenue for further research. 


\section{References:}

Allen, S.H. (2005). The determinants of economic sanctions success and failure. International Interactions, 31(2), 117-138. https://doi.org/10.1080/03050620590950097

Altman, D. (2018). Advancing without attacking: The strategic game around the use of force. Security Studies, 27(1), 58-88. https://doi.org/10.1080/09636412.2017.1360074

Ayson, R., \& Pardesi, M.S. (2017). Asia's Diplomacy of Violence: China-US Coercion and Regional Order. Survival, 59(2).

Baldwin, D.A. (1985). Economic Statecraft. Princeton University Press.

Blasko, D.J. (2019). The Chinese Military Speaks to Itself, Revealing Doubts. War on the Rocks. https:// warontherocks.com/2019/02/the-chinese-military-speaks-to-itself-revealing-doubts/

Brooks, S.G., \& Wohlforth, W.C. (2016). The Rise and Fall of the Great Powers in the Twenty-first Century: China's Rise and the Fate of America's Global Position. International Security, 40(3), 7-53. https://doi. org/doi:10.1162/ISEC_a_00225

Bush, N., \& Xu, R. (2021). China's Expanding Economic Sanctions Regime. DLA Piper. https://www.dlapiper. com/en/japan/insights/publications/2021/03/chinas-expanding-economic-sanctions-regime/

Clifton, M.T., Bapat, N., and Kobayashi, Y. (2014). The Threat and Imposition of Sanctions: Updating the TIES dataset. Conflict Management and Peace Science, 31(5), 541-558. http://www.unc.edu/ bapat/TIES.htm

Closing argument. (2021, May 8). The Economist. https://www.economist.com/asia/2021/05/08/australiasdebate-about-china-is-becoming-hot-angry-and-shrill

Drezner, D. W. (2003). The Hidden Hand of Economic Coercion. International Organization, 57(03), 643-659. https://doi.org/10.1017/S0020818303573052

Economy, E. C. (2018). China’s New Revolution. Foreign Affairs. https://www.foreignaffairs.com/articles/ china/2018-04-17/chinas-new-revolution

Farrell, H., \& Newman, A.L. (2019). Weaponized Interdependence How Global Economic Networks Shape State Coercion. International Security, 44(1), 42-79.

Gady, F.-S. (2015). 'Little Blue Men:'Doing China's Dirty Work in the South China Sea. The Diplomat. website: https://thediplomat.com/2015/11/little-blue-men-doing-chinas-dirty-work-in-the-south-china-sea/

Harrell, P., Rosenberg, E., and Saravalle, E. (2018). China's use of coercive economic measures. https://www. cnas.org/publications/reports/chinas-use-of-coercive-economic-measures

Hostage diplomacy. (2021, March 8). The Economist.https://www.economist.com/the-americas/2021/03/08/ only-america-can-break-the-deadlock-between-canada-and-china

Hufbauer, G.C., \& Jung, E. (2020). China plays the sanctions game, anticipating a bad US habit. Peterson Institute for International Economics. https://www.piie.com/blogs/china-economic-watch/chinaplays-sanctions-game-anticipating-bad-us-habit

Kalyanpur, N., \& Newman, A.L. (2018). Mobilizing Market Power: Jurisdictional Expansion as Economic Statecraft. International Organization, 73(1-34).

Laity, M., Nimmo, B., Jackson, L., and Thomas, T. (2015). Information at War: From China's Three Warfares to NATO's Narratives. https://li.com/reports/information-at-war-from-chinas-three-warfares-tonatos-narratives/

Lektzian,D., \& Souva, M.(2003). The Economic Peace between Democracies: Economic Sanctions and Domestic Institutions. Journal of Peace Research, 40(6), 641-660. https://doi.org/10.1177/00223433030406002

Libiseller, C., \& Milevski, L. (2021). War and Peace: Reaffirming the Distinction. Survival, 63(1), 101-112. https://doi.org/https://doi.org/10.1080/00396338.2021.1881256 
Martinson, R.D. (2018). Echelon Defense: The Role of Sea Power in Chinese Maritime Dispute Strategy. https://digital-commons.usnwc.edu/cmsi-red-books/15/

McLean, E.V., \& Whang, T. (2014). Designing foreign policy: Voters, special interest groups, and economic sanctions. Journal of Peace Research, 51(5), 589-602. https://doi.org/10.1177/0022343314533811

National Security Strategy of United States of America. (2017). https://www.whitehouse.gov/articles/ new-national-security-strategy-new-era/

Pape, R.A. (1997). Why Economic Sanctions do not work. International Security, 22(2), 90-136.

Poast, P. (2020). Competitors, Adversaries, or Enemies? Unpacking the Sino-American Relationship. War on the Rocks https://warontherocks.com/2020/10/competitors-adversaries-or-enemies-unpacking-thesino-american-relationship/

Poh, A. (2017). The myth of Chinese sanctions over south China Sea disputes. Washington Quarterly, 40(1), 143-165. https://doi.org/10.1080/0163660X.2017.1302744

Qiao Liang, \& Wang, Xiangsui (1999). Unrestricted Warfare. http://www.c4i.org/unrestricted.pdf

Rajah, R. (2021). The big bark but small bite of China's trade coercion. The interpreter. https://www.lowyinstitute.org/the-interpreter/big-bark-small-bite-china-s-trade-coercion

Swaine, M.D. (2018). Chinese Views of Foreign Policy in the $19^{\text {th }}$ Party Congress. China Leadership Monitor, (55).

Swept up in a storm. (2021, March 31). The Economist. https://www.economist.com/business/2021/03/31/ consumer-boycotts-warn-of-trouble-ahead-for-western-firms-in-china

Weiss, J.C. (2019). How Hawkish Is the Chinese Public? Another Look at "Rising Nationalism" and Chinese Foreign Policy. Journal of Contemporary China, 28(119), 679-695. https://doi.org/10.1080/10670564 .2019 .1580427

Wisniewski, R. (2018). EU-NATO cooperation in countering hybrid threats: comparing capabilities and defining roles. In C. Morsut \& D. Irrera (Eds.), Security Beyond the State. The EU in an Age of Transformation. Barbara Budrich Publishers.

Wisniewski, R., \& Hensarling, B. (2015). Power in 2025: A Global Ranking. R/Evolutions Global Trends \& Regional Issues, 3(1), 122-157.

Xiaolin, Duan. (2017). Unanswered questions: Why we may be wrong about Chinese nationalism and its foreign policy implications. Journal of Contemporary China, 26(108), 886-900. https://doi.org/10.10 80/10670564.2017.1337312

Zhao, T. (2010). Sanction experience and sanction behavior: An analysis of Chinese perception and behavior on economic sanctions. Contemporary Politics, 16(3), 263-278. https://doi.org/10.1080/13 569775.2010 .501639 